\title{
JURNAL RISET BISNIS DAN MANAJEMEN
}

https://journal.unpas.ac.id/index.php/jrbm/index

\section{MARKETING SRATEGY AT MANGO DAY BY USING SWOT ANALYSIS METHOD}

\author{
Dila Sari Annisa ${ }^{1} \bowtie$, Irfan Ardiansah $^{2}$, Totok Pujianto ${ }^{3}$ \\ Universitas Padjadjaran \\ \dila16001@mail.unpad.ac.id
}

Jl. Raya Bandung Sumedang KM.21, Jatinangor, Sumedang 45363

\begin{abstract}
Mango Day is small medium industry that echoes a healthy lifestyle as one of their visions with fruit strip as their product made from dried mangoes. The purpose of this research is to get the best marketing strategy for the Mango Day business. This research is a qualitative research with data collection techniques for instance, interviews, observations, and documentation with analytic descriptive results. The SWOT analysis technique is used to process data to obtain alternative strategies. There are four alternative strategies that can be used by companies as the company's latest marketing strategy. SO strategy: maintaining product quality and creating new product variants, ST strategy: intensifying marketing on social media and other E-commerce is inserted with knowledge of products to be affordable to all groups and to expand the spread of products offline. WO Strategy: improve the quality of packaging and WT strategy: improve production processes to industrial scale.
\end{abstract}

\section{Article Info}

Mistory Of Article

Received: 5/1/2021

Revised: 26/1/2021

Accepted: 22/2/2021

Jurnal Riset Bisnis dan

Manajemen

Volume 14, No. 1, February

2021, Page. 24-30

ISSN 1979-0600 (print)

2580-9539 (online)

Keywords: small-medium enterprise; SWOT analysis; marketing strategy; e-commerce

\section{INTRODUCTION}

The Data from Central Statistic Agency's (Badan Pusat Statistik/BPS) in 2012 stated that industrial sector is able to absorb a workforce of 15.37 million people out of available 118 million people and $61.57 \%$ out of those absorption is absorbed by the small medium industry. Small medium industry (SMI) is a part of industrial sector which actively producing and generally its marketing activity is assisted by small medium enterprise. SMI has an important role on the rise of employment number due to its ability to absorb labor. SMI and micro small medium enterprise have absoption level of $97 \%$ out of total national employment and contribute around 57\% toward Gross Domestic Product (GDP) (Sarwono, 2015).

SMI is one of the govenrment pedestals in creating new jobs and employment especially after economy's crisis few years back. SMI is also a very important part from a country's economy, including Indonesia. As an illustration, even though the contribution of the SMI sector to the national output (GRDP) in 2000 was only 56.7 percent and in non-oil and gas exports only 15 percent in 2000, SMI has contributed as much as 99 percent in the number of business entities in Indonesia and had a share as much as 99.6 percent in labor absorption (Lestari, 2011). SMI is a business founded on individual initiative, can absorb a lot of workforce around it and usually does not have special skills. Production carried out by SMI usually utilizes surrounding resources, both natural and human resources (Safitri, 2017).

SMI is a business group that produces goods or services that can be used for local community consumption or not, it can absorb a lot of labor and often become a source of income for the surrounding community (Nurhayati, 2012). The activity carried out by the industry in processing a raw material into something that increases the selling value of goods and has a higher economic value (Fitriana, et. al., 2014).

According to the Law of the Republic of Indonesia Number 3 of 2014 concerning industry, it is stated that industry is all forms of economic activities that process raw materials and /or utilize industrial resources so as to produce goods that have added value or higher benefits, including industrial services. Industrial service itself is a service business related to industrial activities (Kemenperin, 2014). Other government 
agencies such as the BPS in 2012 defined industry based on the number of workers. The micro industry, for example, is a business unit with up to four permanent workers, 5 to 19 workers in small industries, 20 to 99 workers in medium industries, and large industries with more than 100 workers.

SMI development is an effort to improve the economy because of the potential for SMIs in developing the national economy which is quite large, as well as the large number of people who depend on SMI (Prasnowo et al., 2017). In general, the weaknesses of micro/small businesses is its unprofessional management. Business success is determined by management/employee skills, which included finance, marketing, operations, and human resource management. The results of this study are expected to grow and develop professional micro entrepreneurs to develop Indonesian's interest in entrepreneurship, improve community welfare, increase gini ratio, and urbanization (Rusliati, 2018).

PT. Saudagar Buah Indonesia is a SMI located in Jatinangor, Sumedang Regency and they had engaged in the food industry by producing from raw materials to final products into snacks. The company started selling its products under the brand called Mango Day, it was established in July 2019. The uniqueness of Mango Day products as the initiator of the first fruit strip in Indonesia made products from this PT. Saudagar Buah Indonesia that can easily attract the market from various circles.

Decree of the Head of the Food and Drug Administration of the Republic of Indonesia no. HK.00.05.52.4040 in 9 October 2006 regarding to processed food products in the snack category stated that all foods made from fruit and vegetables (including mushrooms, tubers, nuts including soybeans and aloe vera), seaweed, and seeds are included in the snacks category (Akib, 2006). The Mango Day Fruit Strip product itself is included in the snack category because it is processed from fresh fruit derived from fruit puree which was dried and went through other processes so that it becomes a fruit strip product as it is currently being marketed. According to Akib (2006), fruit puree is a fruit product obtained from the same way as making fruit pulp, but the fibers are separated so that it has a smoother texture which is usually used for pastry, but not limited to pastries.

PT. Saudagar Buah Indonesia was chosen because there were problems in the marketing strategy carried out by PT. Saudagar Buah Indonesia in promoting their products, called Mango Day, which causes the distribution of products to tend to be less developed. This makes the products that have been produced will settle in the warehouse and make the stock pile up, so that production activities must be stopped for a while until the stock starts to run low, approximately 200 pieces.

The sales of a product or service from a company is the result of good performance of marketing strategy of the concerned company. The amount of competition in small-medium industries required companies to have a good strategy so that products and services from these companies can compete and survive in market competition, moreover, it will survive for the long terms. Strategy is a tool to achieve goals related to the long-term goals of the company (Rangkuti, 2016).

The meaning of marketing is often confused with the meaning of sales, trade and distribution, while actually these terms are only one part of the overall marketing activity. The marketing process had been starting a long time ago before goods were produced and not ended with sales but how to provide satisfaction to consumers (Andika \& Susanti, 2018). Marketing is an activity process that is influenced by various social, cultural, political, economic and managerial factors. These factors cause each individual and group to get what they need and want by creating, offering, and exchanging products that have commodity values (Rangkuti, 2016).

The formulation of a marketing strategy is based on a thorough analysis towards the influence of the company's external and internal environmental factors, and tends to change. Companies must be able to read changes in the company's external environment that can change in many circumstances, so that opportunities and threats both from competitors and the ever-changing rhythm of the business can be read and overcame. The consequences of this is that internal company factors such as company strengths and weaknesses will change. For the companies to see and improve the internal and external conditions of their company, it is necessary to develop a marketing strategy so that in the future the company can anticipate changes from its external environment which are very important and needed by the company to gain an advantage in competing and produce products that are in accordance with consumer desires (Rangkuti, 2016).

Strategic planning is carried out on the basis of institutional aspects and aspects of consumer preferences. The main purpose of making a company strategy is to be able to objectively see internal and external conditions so that they can anticipate changes that occur (Wiyono, 2019). The marketing strategy that should be carried out by companies so far is the B2B or Business to Business concept, which means that products from the company are sold through other companies, such as retailers, resellers and distributors. on the other hand, practically, companies are likely to apply the concept of B2C or Business to Customer, it does mean that the products from the company are sold directly to buyers as a result of selling through 
E-commerce, and also mostly the knowledge about the product's existence has not yet been spreaded to the public. This has led to the need for an analysis of the marketing strategies that have been carried out by Mango Day in promoting its products.

Methods that can be used to analyze marketing strategies include the SWOT, QSPM, and SOSTAC® methods. The method used in this research is the SWOT method, which is the most commonly method for assessing strategy (Basset, et. al., 2018). The SWOT method examines the strengths (S), weaknesses $(\mathrm{W})$, opportunities $(\mathrm{O})$ and threats $(\mathrm{T})$, to select and implement the best strategy to achieve organizational goals (Basset, et. al., 2018). SWOT analysis is used to determine important factors for sustainable planning (Ahmed, et. al., 2019). Using a correlative interpretation of a SWOT analysis, it can be understood that opportunities and threats are always potential, depending on the strategic ability of the organization to use its strengths and weaknesses in comparison (Charis, 2019). SWOT analysis can also be applied at the individual level to further assess a person's situation versus their competition (Teoli, et. al., 2019) The SWOT method is useful in conducting strategic analysis, so that it is expected to be able to minimize weaknesses in a banking institution and reduce the impact of threats that arise and must be faced (Chrismastianto, 2017).

\section{METHOD}

This research uses qualitative research methods with data collection techniques such as interviews, field observations, and documentation with analytical descriptive results. The research begins with conducting a preliminary study, they are observation, literature study and obtaining output in the form of problem identification and goal setting of this study. The next stage is to make observations and interviews with the internal section of Mango Day, then then the data is analyzed by using the SWOT method.

Strengths, Weaknesses, Opportunities, and Threats or SWOT for short is one of the most well-known strategic planning tools and is used in many problem management (Nazarko, et. al., 2017). Strengths identified through a SWOT analysis must be "leveraged", weaknesses must be "fixed", opportunities need to be "accepted" and finally, threats can be reduced if there is "awareness" about the same thing (Pandya, 2017). SWOT analysis is a powerful approach to evaluate organizational strengths and weaknesses from an internal perspective by taking into account opportunities and threats from an external perspective of the company (Büyüközkan \& Ilıcak, 2019). SWOT analysis is widely chosen for analysis because of its simplicity which allows everyone to participate without requiring substantial technical support (Pesce, et. al., 2018).

The purpose of using SWOT in analyzing the performance of a company is so that the company can determine realistic business goals and in accordance with company conditions, so that these goals are more easily achieved (Siswanto \& Kleinsteuber, 2011). If a company knows how to develop strengths, improve weaknesses, take opportunities and avoid threats that will be suffered by the company, it is certain that the company will be superior to existing competitors. (Andrariladchi \& Adiwibowo, 2018).

\section{RESULTS}

SWOT analysis includes internal and external factors of the company. Internal company factors include Strengths and Weaknesses as well as external factors, they are Opportunities and Threats contained in IKM Mango Day are: (1) internal factors, strengths (no competitors for similar products, products contains nutrients like real fruits, active in social media), weaknesses (fragile products, easily damaged, high production cost, raw material's cost fluctuative due to seasons), (2) external factors, opportunities (healthy lifestyle trends is emerging in big cities, no competitors existed, suitable for sports lover), threats (low product's awareness, uneven product's distribution, quite expensive product's price).

The results of the SWOT analysis are compared with external factors, opportunities and threats, with internal factors of strengths and weaknesses (Nasution et al., 2020). Internal factors are entered into a matrix called the internal strategic factor matrix or IFAS (Internal Strategic Factor Analysis Summary). The IFAS matrix serves to determine the results of the strengths and weaknesses indicators seen from the quality of the item multiplied by the rating (Rusby \& Arif, 2020). External factors are entered into a matrix called the external strategic factor matrix EFAS (External Strategic Factor Analysis Summary) (Nisak, 2013). IFAS matrix, EFAS matrix and SWOT matrix analysis can be seen in the Table 1, Table 2, and Table 3. 
Table 1. Mango Day IFAS Matrix

\begin{tabular}{lccc}
\hline \multicolumn{1}{c}{ Internal Factors } & Weight & Rating & Score \\
\hline & Strength & & \\
\hline No competitors for similar products & 0.15 & 4 & 0.6 \\
Products contains nutrients like real fruits & 0.13 & 3 & 0.39 \\
Active in social media & 0.19 & 2.5 & 0.475 \\
Sub Total & 0.47 & & 1.465 \\
\hline \multicolumn{2}{c}{ Weakness } \\
Fragile products, easily damaged & 0.16 & 3 & \\
High production's cost & 0.11 & 2 & 0.48 \\
Healthy lifestyle trend is not that hype & 0.17 & 3 & 0.22 \\
Raw material's cost fluctuative due to seasons & 0.09 & 2.5 & 0.51 \\
Sub Total & 1 & & 0.225 \\
\hline \multicolumn{1}{c}{ Total } & & 2.435 \\
\hline
\end{tabular}

Source: Data Analysis (2021)

Table 2. Mango Day EFAS Matrix

\begin{tabular}{|c|c|c|c|}
\hline External Factor & Weight & Rating & Score \\
\hline \multicolumn{4}{|c|}{ Opportunity } \\
\hline Healthy lifestyle trends is emerging in big cities & 0.18 & 3.7 & 0.666 \\
\hline Suitable for sports lover & 0.18 & 2.4 & 0.432 \\
\hline No competitor existed & 0.2 & 4 & 0.8 \\
\hline Sub Total & 0.56 & & 1.898 \\
\hline \multicolumn{4}{|c|}{ Threats } \\
\hline Low product's awareness & 0.2 & 3 & 0.4 \\
\hline Uneven product's distribution & 0.13 & 3 & 0.26 \\
\hline Quite expensive product's price & 0.11 & 3 & 0.33 \\
\hline Sub Total & 1 & & 0.99 \\
\hline Total & & & 2.888 \\
\hline
\end{tabular}

Source: Data Analysis (2021)

Tabel 3. Mango Day SWOT Matrix Analysis

Strength (S): $\quad$ Weakness (W):

1. No competitors for similar products

1. Fragile products, easily damaged

2. Products contains nutrients like real fruits

3. Active in Social Media

2. High production's cost

3. Raw material's cost fluctuative due to seasons

\begin{tabular}{|c|c|c|}
\hline $\begin{array}{l}\text { Opportunities }(\mathrm{O}) \text { : } \\
\text { 1. Healthy lifestyle trends is emerging in } \\
\text { big cities } \\
\text { 2. No competitors existed } \\
\text { 3. Suitable for sports lover }\end{array}$ & $\begin{array}{l}\text { SO Strategy: } \\
\text { 1. Mantain product's quality (S2, O1) } \\
\text { 2. Creating new product's variance (S1, S2, } \\
\text { O2) }\end{array}$ & $\begin{array}{l}\text { WO Strategy: } \\
\text { Upgrade packaging's quality (W1, O2) }\end{array}$ \\
\hline $\begin{array}{l}\text { Threat }(\mathrm{T}) \text { : } \\
\text { 1. Low Product's awareness } \\
\text { 2. Uneven product's distribution } \\
\text { 3. Quite expensive Product's price }\end{array}$ & $\begin{array}{l}\text { ST Strategy: } \\
\text { 1. Intensify marketing on social media } \\
\text { and other e-commerce with product's } \\
\text { knowledges to make it accessible to all } \\
\text { people (S3, T1) } \\
\text { 2. Expand offline product's distribution } \\
\text { through retailers, resellers and distributors } \\
\text { (S1, T1, T2)secara offline melalui retailer, } \\
\text { reseller dan distributor }(\mathrm{S} 1, \mathrm{~T} 1, \mathrm{~T} 2)\end{array}$ & $\begin{array}{l}\text { WT Strategy: } \\
\text { Increase business scale to industrial scale } \\
(\mathrm{W} 2, \mathrm{O} 2, \mathrm{O} 3)\end{array}$ \\
\hline
\end{tabular}




\section{DISCUSSION}

Strength posessed by Mango Day are: (1) there are no competitors with similar products. So far, in Indonesia there are no companies that produce fruit strips. The competitors that have been found to date are in the United States, (2) the product has nutritional content such as real fruit. The use of dehydration technology in the production process does not damage the contents of the mango fruit, (3) active on social media. Companies that are active on social media make consumers feel closer so that they hold trust in buying products from the company.

Weaknesess posessed by Mage Day are: (1) fragile products, easily damaged. Products are not supported by resilient packaging yet, (2) high production's cost. Due to other expenses such as production house and employee's salary, (3) healthy lifestyle trends is not sufficient enough causing low market. The number of people who concerned with their health is not that high, causing customers choose products with no nutrition and cheaper price, (4) raw material's cost fluctuative due to seasons. Due to Mango only harvested once a year in short period (October - December) causing significant price's different outside those month (Yuniastuti \& Purbiati, 2016).

The opportunities that can be taken by Mango Day are: (1) healthy lifestyle trends is emerging in big cities. The increasing trend of healthy lifestyle in big cities has made people to start looking for products with nutritional content as a substitute for snacks or junk food, (2) suitable for sports lover. Its good nutritional content, such as real fruit, makes Mango Day enjoyable for sports lovers without fear of damaging the current health program, (3) no competitors exist so that company can control prices. Being a pioneer in the production of fruit strips allows Mango Day to control product prices that befit all parties.

The threats that can be acknowledged for Mango Day are, (1) low product's awareness in society. This results in the need for more intensive provision of knowledge about products to the community so that it spends most of the marketing costs, (2) uneven product's distribution in offline market. Limited availability of offline products makes people often change their choice of buying products that can be enjoyed at that moment, (3) quite expensive product's prices. This is because the large number of costs outside productions which can be reduced if the scale of production is increased.

SO Strategy: (1) maintaining product's quality. Mango Day as the pioneer of the first fruit strip in Indonesia with a dehydration method that is able to fill people's needs for healthy and nutritious snacks. The fruit strip production process has implemented good SOP and HACCP so that it can maintain the quality of the products, (2) creating new product's variance. The number of other fruit variants that can be used as a base for fruit strips can be used as an opportunity to reach and attract more markets.

ST Strategy: (1) intensifying marketing on social media and other e-commerces with product's knowledge. Mango Day's activeness on social media can be used as a marketing medium that is quite effective in reaching consumers. Direct involvement between consumers and companies can psychologically affect consumers so that they have more confidence in buying products from these companies, (2) expanding offline product's distribution through retailers, resellers, and distributors. Giving special prices for retailers, resellers and distributors is expected to attract the attention of potential business partners therefore, they have the desire to join. Adding business partners to sell products offline aims to bring the product closer to consumers in order to make them want to buy products can finally get one immediately without having to wait for delivery times which takes of up to 2-3 days at least.

WO Strategy, upgrade packaging's quality. The quality of packaging from Mango Day now is only in the form of laminated paper packaging with aluminum coated on the inside. Packaging like this is less able to protect the product from collisions so there is a moment when you open the product some of them were already destroyed. It is better if the company adds a more resilient material, at least a material that is hard enough like cardboard on the back. Packaging with vacuum technology can also protect the product better so that it can minimize the destruction of the product when it reaches the consumer. WT Strategy, increase business scale to industrial scale. Increasing the scale of the business from home productions to industry can make the actual costs of expenses reduce if the scale of the business switches to industry.

\section{CONCLUSION}

Based on analysis, it is concluded that obtained a value of 2.9 for the IFAS matrix, influenced by factors that there are no competitors for similar products in Indonesia, even in Asia. New competitor who has similar products is in the United States, while the company's most influential weakness is that there are still few people who apply healthy lifestyle in their daily lives. The value for the EFAS matrix is 2.888 which is strongly influenced by the absence of competitors, while the most influencing factor in terms of threats is the 
low product's awareness by the wider community so that people tend to choose products that are commonly consumed even though they have no nutritional value. The strategies included maintaining product quality, creating new product variants, intensifying promotion on social media, expanding offline product distribution, upgrading packaging quality, and increasing business scale to industrial scale.

\section{REFERENCES}

Abdel-Basset, M., Mohamed, M., \& Smarandache, F. 2018. An Extension of Neutrosophic AHP-SWOT Analysis for Strategic Planning and Decision-Making. Symmetry. https://doi.org/10.3390/sym10040116 Ahmed, Y., Mirjat, N. H., Ali, S., \& Tan, Q. 2019. Evaluating the strategies for sustainable energy planning in Pakistan: An integrated SWOT-AHP and Fuzzy-TOPSIS approach. Journal of Cleaner Production, 236. https://doi.org/10.1016/j.jclepro.2019.117655

Akib, H. 2006. Decree of the Head of the Food and Drug. Administration of the Republic of Indonesia. (Surat Keputusan Kepala Badan Pengawas Obat dan Makanan Republik Indonesia).

Andika, A., \& Susanti, F. 2018. Pengaruh Marketing Mix Terhadap Keputusan Pembelian Parfum Di Azzwars Parfum Lubeg Padang. Pundi, 1.

Andrariladchi, H., \& Adiwibowo, B. 2018. Pengembangan Strategi Public Relations Menggunakan Pendekatan Marketing Mix dan SOSTAC terhadap Produk Pariwisata. 3, 219-229.

Basset, M. A., Mohamed, M., Sangaiah, A. K., \& Jain, V. 2018. An Integrated Neutrosophic AHP and SWOT Method for Strategic Planning Methodology Selection. Benchmarking: An International Journal, 25. https:// doi.org/10.1108/BIJ-08-2017-0232

BPS. 2012. Jumlah Tenaga Kerja Industri Mikro dan Kecil Menurut Provinsi, 2013-2015.

Büyüközkan, G., \& Ilıcak, Ö. 2019. Integrated SWOT Analysis with Multiple Preference Relations: Selection of Strategic Factors for Social Media. Kybernetes, 48(3). https://doi.org/10.1108/K-12-2017-0512

Charis, V. 2019. On a Correlative and Evolutionary SWOT Analysis. Journal of Strategy and Management, 12. https://doi.org/10.1108/JSMA-02-2019-0026

Chrismastianto, I. 2017. Analisis Swot Implementasi Teknologi Finansial Terhadap Kualitas Layanan Perbankan Di Indonesia. Jurnal Ekonomi Bisnis, 20.

Fitriana, A., Noor, I., \& Hayat, A. 2014. Pengembangan Industri Kreatif Di Kota Batu. Jurnal Administrasi Publik Mahasiswa Universitas Brawijaya, 2(2), 281-286.

Kemenperin. 2014. Undang-Undang Perindustrian no. 3.

Kotler, P., \& Keller, K. 2009. Manajemen Pemasaran (13th ed.). Penerbit Erlangga.

Lestari, E. P. 2011. Penguatan Ekonomi Industri Kecil dan Menengah Melalui Platform Klaster Industri. Jurnal Organisasi Dan Manajemen, 7.

Nasution, A., Azmi, N. N., Ananda, F. P., \& Azalia, M. 2020. Disturbance Management Strategy in the Food Supply Chain in The Middle of Pandemic COVID-19. IOP Conference Series: Materials Science and Engineering. https://iopscience.iop.org/article/10.1088/1757-899X/1003/1/012133

Nazarko, J., Ejdys, J., Halicka, K., Magruk, A., Nazarko, Ł., \& Skorek, A. 2017. Application of Enhanced SWOT Analysis in the Future-oriented Public Management of Technology. Procedia Engineering, 182. https://doi.org/10.1016/j.proeng.2017.03.140

Nisak, Z. 2013. Analisis Swot Untuk Menentukan Strategi Kompetitif. Jurnal Ekbis, 9.

Nurhayati, S. 2012. Peran Dinas Perindustrian dan Perdagangan dalam Pengembangan Industri Kecil Menengah di Kota Surakarta.

Pandya, S. 2017. Improving the Learning and Developmental Potential of SWOT Analysis: Introducing the LISA Framework. Strategic Direction, 33(3). https://doi.org/10.1108/SD-09-2016-0132

Pesce, M., Shi, C., Critto, A., Wang, X., \& Marcomini, A. 2018. SWOT Analysis of the Application of International Standard ISO 14001 in the Chinese Context. A Case Study of Guangdong Province. Sustainability, 10. https://doi.org/10.3390/su10093196

Prasnowo, M., Khomaruddin, A., \& Hidayat, K. 2017. Strategi Pengembangan Sentra Industri Kecil Menengah Produksi Krupuk. Teknika. Engineering and Sains Journal, 1.

Rangkuti, F. 2016. Analisis SWOT: Teknik Membedah Kasus Bisnis. PT. Gramedia.

Rusby, Z., \& Arif, M. 2020. Development of Sharia Tourism in Riau Province Indonesia. African Journal of Hospitality, Tourism and Leisure, 9. https://www.ajhtl.com/uploads/7/1/6/3/7163688/article_71_ vol 912020 indonesia.pdf

Rusliati, E. $\overline{\text { E}}$ 2018. Microcredit For Micro-Entrepreneurs Development in Ende District. Jurnal Riset, Bisnis Dan Manajemen, 11(2).

Safitri, E. 2017. Perkembangan Industri Kecil Dan Menengah Di Kabupaten Merangin. UTILITY: Jurnal 
Ilmiah Pendidikan Dan Ekonomi, 1.

Sarwono, H. 2015. Profil Bisnis Usaha Mikro, Kecil dan Menengah (UMKM). Lembaga Pengembangan Perbankan Indonesia.

Siswanto, S., \& Kleinsteuber, F. 2002. Strategi Manajemen Penasaran. Penerbit Damar Mulia.

Teoli, D., Sanvictores, T., \& An, J. 2019. SWOT Analysis. StatPearls Publishing.

Wiyono, G. 2019. SWOT Dan Analytic Hierarchy Process Sebagai Acuan Strategi Optimasi Student Body. Jurnal Riset Bisnis Dan Manajemen, 12(1).

Yuniastuti, S., \& Purbiati, T. 2016. Pengaruh Penambahan Pupuk Hayati dan PPC Terhadap Keberhasilan Pembuahan Mangga Podang di Luar Musim (Effect of Biofertilizer and Liquid Fertilizer on Off-Season Podang Mango Fruiting Success). 